17 Shaper AG. Walker M, Wannamethee (i. Alcohol and mortality in British men: explanning the U'-shaped curve. Lanet 1988: ii:1267-73.

is ber AR, Stamler J, Paul O. Lepfer .II, Shekelle RB, et al. Alcohol consumption and 17-year mortality in the Chicago Western Electric Company studv. 7 Prec Med 1980;9:78-90.

19 Friedman LA, Kimball AW'. Coronary heart disease mortality and alcohol consumption in Framingham. Am 7 Fipidemiol 1986:124:481-9.

20 Yano $K$, Rhoids (iG, Kagan A. Coffece, alcohol and risk of coronary hear disease among Japanese men living in Hawaii. N Eingl f Med 1977.297: +05-9.

21 Kono S, Ikeda M, Tokudone S, Nishizumi M, Karatsune M. Alcohol and mortalitv: a cohort study of male Japanese physicians. Int $\mathcal{f}$ Eipidemiol 1986:15:527-31.

22 Kimner SJ, Garcia-Palmieri MR, Costas R, Cruz-Vidal M, Ahbou RI), Havlik RJ. Alcohol and coronars heart disease in Puerto Rico. Am 7 Epidemol 1983:117:538-50.

23 Criqui MH, Cowan LD, Tyroler HA, Bangdiwala S, Heiss G, Wallace RB, it al. Lapoproteins as mediators for the effects of alcohol consumption and cigarette smoking on cardiovascular mortality: results from the lipid research dinics follow-up study. A 7 F Epidemiol 1987;126:629-37.

24 Miller (i). Bcikles GLA. Maude (iH, Carson DC. Alcohol consumption: protection against coronary heart disease and risks to health. In 7 Epidemiol 1990;19:923-30.

25 Marmot MG, Rose G, Shiples MJ, Thomas BS. Alcohol and mortality: u-shaped curve. Lancet 1981:1:580-3.

26 Kozarevic D. Vojvodic N, Gordon T, Kaelber C, McGee D, Zukel W'J. Drinking habits and death. Int 7 Lipidemiol 1983:12:1+5-50.
27 Cullen K. Stenhouse NS, Wearne KL. Alcohol and mortality in the Busselton study. In f Epidemiol 1982;11:67-70

28 Klatsky AL, Armstrong MA, Friedman (iD). Relations of alcoholic beverag use to subsequent coronary artery disease hospitalization. Am f Curdiol 1986;58:710-4.

29 Stampfer MJ, Colditz (iA, Willett WC, Speizer FE, Hennekens $\mathrm{CH}$. A prospective study of moderate alcohol consumption and the risk of coronary disease and stroke in women. $N$ Engl 7 Med 1988:319:267-73.

30 Criqui $\mathrm{MH}$. The reduction of coronary heart disease with light to moderate alcohol consumption: effect or artifact? Br 7 Addict 1990;85:854-6.

31 Shaper AG. Alcohol and mortality: a review of prospective studies. Br F Addic 1990:85:837-47.

32 Klatsky AL, Armstrong MA, Friedman GD. Alcohol and cardiovascular deaths. Circulation 1989;80:611-4.

33 Klatsky AL, Armstrong MA, Friedman GD. Mortality in ex-drinkers. Circulation 1990:81:720.
.

34 Castelli WP, Doyle JT, Gordon T. Alcohol and blood lipids. The cooperative lipoprotein phenotyping study. Lancet 1977; ii: 153-5.

35 Meade TW, Chakrabarti R, Haines AP. Characteristics affecting fibrinolytic activity and plasma fibrinogen concentrations. BMJ 1979;i:153-6.

36 Duffy JC. Fallacy of the distribution of alcohol consumption. Psychol Rep 1982:50:125-6.

37 Rose (i, Day S. The population mean predicts the number of deviant individuals. BMf 1990;301:1031-4

Accepted 29 fuly 1991
Division of Social and Behavioral Medicine, University of Medicine and Dentistry of New Jersey, New Jersey 08103, US Donald W Light, PHD, professor

\title{
Observations on the NHS reforms: an American perspective
}

\author{
Donald W Light
}

In the waiting rooms of family practices across the US patients can pick up a prominently displayed, large, four colour, free Special Report on Health featuring a story of the Montagues, entitled, "Can you afford to get sick?"' Their daughter contracted leukaemia, and, although this middle class family has standard health insurance, the parents have spent the past three years dealing with scores of different claim forms, deductibles, copayments, caps, exclusions, and erroneous (perhaps) denials in order to cope with the $\$ 500000$ of bills for treating her.

The report pictures Mrs Montague before a dining table covered with seven piles of different correspondence over bills and claims; boxes full of files for each doctor, laboratory, and hospital; and even a photocopier she bought to help in the fight against constant threats of financial ruin. An accompanying article features Dr Niles, a physician on the other side of the private competitive insurance market. ${ }^{2} \mathrm{He}$ is seen coping with myriad insurance forms and hundreds of provisos, protocols, or rules that insurance companies have elaborated as the counterparts to the exclusions, deductibles, copayments, and caps for Mrs Montague. Each elaboration serves to reduce payments by the insurers or to delay what has to be paid so that the insurance companies can earn more interest on the premium income. All Mrs Montague wants is to have the bills for her daughter Jenni paid. All Dr Niles wants is to be paid for the services he renders.

With about 35 million Americans being uninsured and about 70 million more suffering from private Swiss cheese policies full of holes in coverage, at the same time that medical expenses have surged past $12 \%$ of the gross national product and the $\$ 600 \mathrm{bn}$ mark, an American observer is hardly in a position to say anything critical about the NHS reforms. Yet it is perhaps just this experience with payer and provider markets over the past 10 years (during which costs rose faster than before the market reforms began) and a Yankee bred outlook on human folly that may provide a valuable perspective.

\section{Upending an efficient system}

To start at the bottom line, the vigorous effort by
Mrs Thatcher, Mr Clarke, and officers in the Treasury to wrench the NHS out of its allegedly wasteful, inefficient, and expensive ways seems strange to a student of comparative health care systems. Do they not know that they were (and are) getting better value for money than any other system in the industrialised world ? ${ }^{3}$ No other system comes close in services per thousand pounds, even after taking into account the million patients waiting for elective procedures.

Do they not know that experts from other systems marvel at how hard British nurses, technicians, and physicians work for so little pay? The level of dedication measurable in services rendered per million pounds of pay provides this government with one of the greatest bargains in the world. Moreover, medical expenditures have been rising more slowly than in any comparable system. Yet the government's response has been to purchase services at marginal rather than average costs, forcing the whole NHS to become run down, while all the time complaining about how expensive the system is.

Ironically, this systemic parsimony has made the NHS steadily more inefficient: equipment breaks down, inefficient or obsolete equipment is not replaced, arrangements are not replaced, poor working conditions and pay contribute to high staff turnover, and a growing number of people opt out of the system through private insurance whenever they can. Thus the government is running down what many used to perceive as a competent, inexpensive, universal health care system. The alternative private system will be much more expensive. These private costs, however, will not show up on the bills that the government pays

To summarise, the restructuring of a system that delivers more services per million pounds than any other on the grounds that it does not do so seems insane. Were the cost of the NHS $£ 45 \mathrm{bn}$ and rising at $5 \%$ over inflation it would be understandable why the government thought it had a problem; but with NHS costs at $£ 30 \mathrm{bn}$, rising at $2 \%$ over inflation, the question is why do British leaders think they can treat the nation's ill for a third less than anyone else?

Although the government apparently intends the reforms to make the NHS more efficient, their latent function is to transfer the political heat of parsimony from politicians to managers and doctors in the guise of 
"inefficiency." As the government has not been able to take the political heat of closing down a couple of London hospitals or making consultants more accountable to the public's needs, it is using competitive contracts to pit the players against one another and let them do the job.

This political benefit, however, will be shortlived; for the basic shift from leaving allocation in the hands of physicians to rationalising care through outcomes, audits, and protocols destroys the buffer of professional discretion which has served so well to protect government from being accountable for how money is spent. This does not mean that variations in practice should not be reduced, outcomes measured, or costs calculated - only that politically the veil of professional discretion will no longer be there to hide behind.

By pointing out the overall "efficiency" of the NHS compared with other systems I do not deny that internal inefficiencies are extensive. On the contrary, my investigations of the subject identify more inefficiencies than have those of the government, ${ }^{4-6}$ but my analysis differs in two ways. Firstly, I know that there is no other system which does not have as many or more inefficiencies. We need to be realistic about what can be done in an emotionally laden service for ill defined problems whose treatment has a contingent, trial and error character. Secondly, most of the inefficiencies are embedded in professional prerogatives, beliefs, and organisation that competitive markets wil not affect. ${ }^{7}$ They need careful analysis and well designed programmes to change current patterns and reduce variations.

For example, the inefficiencies of what the British call "waiting lists" will not be resolved by simple competitive pressures. Careful observation of how the lists work, as carried out by Catherine Pope, ${ }^{8}$ shows that they are not a first come, first served queue but more like a singles dance, where (simply) the gals whom the guys pick are determined by what the guys are looking for, how much time they have, and how skilfully or persistently the chosen put themselves in the minds of the choosers. Perhaps waiting lists are even more like a waiting game and the patients are contestants. With budget holding general practitioners, some of the contestants now have sponsors as well.

The point is that "inefficiency" here is a useless, even misleading, term, as is the credo, "Competition produces efficiency." Without thinking through the sociological dynamics of waiting and how they should change, competition will just shuffle around who waits longer and who waits less.

\section{Hand to mouth policy?}

With this overview we can turn to the new emphasis on purchasing. Looked at from a longer perspective, this emphasis is merely the latest in a series of hand to mouth shifts as the nation's leaders try to correct one error or imbalance after another resulting from the powerful and dangerous market forces they have unleashed. These leaders have put themselves in the position of being the "rules committee" of a new game in which they also serve as the recruiters, trainers, and coaches for both sides as well as the referees of the game as it is being played.

To this observer, then, the reforms began as dictated competition, a troubling concept from Eastern Europe. "When we say go, you will start to compete.... GO" Then, almost as soon as the game began, the rules committee realised the dislocations that could arise from what the first round of contracts would leave out and ordered that all arrangements must be the same as before, only in the form of contracts. While the committee sees this move as simply delaying the game to give the players more time to hone their skills, it has the effect of locking in to the first round of contracts the old arrangements they were intended to overthrow. Although change is happening, this greatly reduces its scope. "Smooth takeoff" and "seamless transition" are phrases whose meaning boils down to "pleasing providers who might cause upset."

Next, the word "contract" seemed dangerously powerful; so the committee changed the term to "agreement" and then to "commissioning." No one is quite sure what "commissioning" means (unless it means contracting), and the committee is still searching for better language. The question is whether the words change much or whether they are like all the pads added to American football as it developed: it's still a game of tackle, preferably hard and low. But the intent is to create consensus management - an echo of the mid-1970s.

Then, when the rules committee started to recruit for their all-star first team of self governing trust hospitals to show the nation how terrific the new game of "Medicine through markets" could be, most of the first draft turned in weak or even financially unsound business plans. ${ }^{9}$ So the committee quickly changed the rules and tightened the financial reins on the trusts to the point that some trust executives are no longer sure what being a trust hospital means.

The national draft for general practitioner budget holders has worked better because it has been confined to the largest practices with good management skills. Budget holding has given these practitioners the power to demand more prompt and better specialty services for their patients and even to restructure arrangements between themselves and specialists. However, distortions are close at hand. Budget holders have a natural monopoly over their lists and can use their budgets to extend their monopoly power vertically, by forming corporations from which they buy the specialty services. ${ }^{10}$ On the contracting side, most general practitioners lack good data on the actual services their patients need or use, so they are contracting somewhat in the dark. Finally, they buy only a limited list of services for just their patients, thereby disrupting the mandate of the district health authorities to purchase for the needs of the entire population. We can expect the rules committee to alter this part of the game in the not too distant future.

The problem that contracts lead to discrimination is bubbling up as an issue. One kind is the extracontractual referral. General practitioners worry that their patients whom contracts have made into extracontractual referrals may not get the specialty care they need. If they do, hospitals worry that not all such referrals are being registered on their books and that therefore they will not get paid. District health authorities worry that as purchasers they are paying for extracontractual referrals that were created for the record. Extracontractual referrals reflect a core problem that arises when a national delivery system is broken up into contracts.

Contracts also imply preferential treatment for patients whose sponsor wields a financial stick over consultants, and when this issue arose the secretary of state initially indicated that such was the natural power and benefit of contracting. Objections intensified, however, not from the consumers (patients), who would be left to wait longer, but from consultants who disliked being put in such a position (as if they had never done so before); and in a major concession that further weakens the original model, the "rules committee" recently agreed joint guidance with the Joint Consultants Committee (though in somewhat "weasly" terms as one observer put it), that the contracts of one purchaser are not to "disadvantage the patients of other purchasers." 


\section{New emphasis on purchasing}

Now the rules committee has suddenly realised what many of the players told me over a year ago, that the purchasers are no match for the providers. ${ }^{12}$ Much of the top managerial talent has gone over to the provider teams, where salaries have increased substantially. One thinks of the privatised electricity companies, in which top managers have apparently raised their salaries sharply while holding down the wages of workers. ${ }^{13}$ Privatising established monopolies does not make much sense, but if that is what the duly elected members of parliament want, why not? The providers, of course, know their game inside out whereas the purchasers were all administrators until just a year ago.

The irony of this latest policy shift is that originally the rules committee did not really want a true Adam Smith market. They wanted a market in which a single buyer would lay down the rules and pit thousands of little provider-sellers against each other. Now they are realising, as I wrote nearly a year ago, that physiciansellers have tremendous advantages and can run rings around the buyers once medical services are transformed into a competitive market. ${ }^{12}{ }^{14}$ When physicians and surgeons are contractors and not employed by a contractor (like a hospital) they can affect supply and demand, shape the clinical record to suit their purposes, develop new "products," identify new problems through more refined diagnosis, expand or contract markets, overserve or underserve (whichever is financially beneficial), substitute cheaper services for more costly ones, and corner market niches. In most parts of Great Britain, where it is said that "there are no markets" this really means that there is a provider monopoly.

Thus, while purchasers deserve special attention because they hold the key to constructive reforms, I wonder whether this is guided by more than the rules committee making the latest adjustment to avoid disruptions in the powerful game they have started but do not fully understand. Everyone I talk to feels a rudderless lack of vision. Sir Roy Griffiths echoed this recently in an important lecture that comes close to saying that the market reforms of 1989-90 disrupted the steady progress that started in 1983 to put the NHS under modern management.'

Purchasing has problems that are not yet being addressed. One is that self governing trust hospitals get in the way of purchasing services based on the needs of the people. It gives hospitals additional power, money, and legitimacy just when purchasers would naturally want to take advantage of technical developments that allow much less use of hospitals. Here is a perfect example of where vision matters: are the reforms primarily aimed at making the current system internally more efficient or at reconfiguring services to meet health needs more efficiently overall?

Another problem for purchasing is that it depends utterly on good information about services and prices; yet as one seasoned observer put it, "IT [information technology] is still a disaster."

A third problem is the fate of caring. If a purchaser asks about the benefits of a provider's programme for the mentally handicapped or the very old, by what outcomes can such programmes be justified? What are the benefits of caring in the forthcoming world of contracts based on outcomes? If people who are actually getting worse are made a bit more comfortable and less miserable, by what criteria is it a service worth purchasing?

\section{Private insurance and breakdown of the NHS}

In the mean time, while the rules committee turns to coaching the purchasers, to toning down the action with soft words, and to moving the goal posts further away, a more fundamental process is going on. Two tier medical care is growing apace, because the British, unlike the Canadians, have not passed a law prohibiting private insurance from covering services provided by the national system. The reason for such a law is clear: private insurers will pick off the more easily insurable services and sell coverage to the most attractive groups, leaving all the people not in firms with insurance perks or with more serious, ongoing problems as the leftovers for the national system. That is what is steadily happening in the United Kingdom, and it has the seductive appeal of upgrading services for those who most demand them without costing Treasury a thing. Did the government really reject converting medical care to a system of private insurance in 1989 as alleged? Or did it just ostensibly reject it?

Thus the leaders of the NHS, the British people, and the medical professions must decide whether to outlaw private insurance that competes with the NHS. Do they want private medicine at higher fees for corporate employees and privileged citizens and public medicine in rundown facilities on the cheap for the rest? The alternative, as Sir Roy Griffiths indicated, is to raise the level of the NHS to the middle class standards of the ' $90 \mathrm{~s}$, and that will not be cheap. The BMA, the royal colleges, and the politicians must decide soon to pass such a law, or private insurance and two tier services will become too pervasive to stop.

1 Gerney C. The Mongagues versus the medical system. Special report on health Knoxville, Tennessee: Whittle Communications, 1991:10-7.

2 Kuznik F. The hassle factor. Special report on health. Knoxville, Tennessee, 1990:23-6.

3 Schieber GJ, Poullier J-P. International health spending: issues and trends. Health Affairs Spr 1991;10:106-16.

4 Light DW. Labelling waste as inefficiency. Health Service fournal 1990;Oct $4: 1470-2$.

5 Light DW. Biting hard on the research bit. Health Service fournal 1990; Oct $25: 1604-5$.

6 Light DW. Medical house arrest. Health Service fournal 1990; Nov 1:1648-9.

7 Light DW. Embedded inefficiencies in health care. Lancet (in press.)

8 Pope C. Trouble in store: some thoughts on the management of waiting lists. Sociology of Health and Illness 1991;13:193-212.

9 British Medical Association Economic Research Unit. Briefing note 1/91. London: BMA, 1991.

10 Ferriman A. GPs cash in on reforms to buy services from own companies. Observer $19917 \mathrm{Jul}: 3$.

11 NHS Management Executive. foint guidance (NHSME/fCC) to hospital consultants on GP fund holding. Appendix I 20GP27/2. London: NHSME June 1991. (Mimeographed.)

12 Light DW. Learning from their mistakes? The Health Service Journal 1990; Oct 4:1470-2.

13 Warner J. Power chiefs pay up 200\%. Independent 1991; 7 July:Sect 1 14 Light DW. Bending the rules. Health Service fournal 1991;Oct 11:1513-5.

15 Griffiths $\mathrm{R}$. Seven years of progress - general management in the NHS. London: Audit Commission, 1991. (Audit Commission management lecture No 3.)

(Accepted 23 fulv 1990) 